\title{
LOST IN TRANSLATION AND THE CRUCIAL PROCESS OF CONVENTION
}

\author{
Witriani ${ }^{1}$, Ulyati Retno Sari ${ }^{2}$, Fuad Arif Fudiyartanto ${ }^{3}$
}

State Islamic University of Sunan Kalijaga Yogyakarta, Indonesia

(si@uin-suka.ac.id)

Received: $18^{\text {th }}$ April 2017; Revised: $25^{\text {th }}$ May 2017; Accepted: $20^{\text {th }}$ June 2017

\begin{abstract}
Certificates, academic transcripts, and name of institutions are such very important academic documents for any institutions, including educational institutions, which translation into foreign languages (for example into English) should be done carefully, thoroughly, and precisely. This research on the translation of such academic documents in UIN Sunan Kalijaga Yogyakarta found that, although in general the translations are correct, there are many parts of the documents that have not been properly translated. Inaccuracies occurs due to frequent inconsistencies in choosing the diction (or vocabulary), phrase structures, and inappropriate choices of the translation procedures. Therefore, the alignment, uniformity, and convention of the translations are necessary to maintain the quality of the results.
\end{abstract}

Key Words: translation; crucial process; convention

\section{ABSTRAK}

Sertifikat, transkrip akademik, dan nama institusi adalah dokumen akademis yang sangat penting bagi institusi manapun, termasuk institusi pendidikan, yang ketika diterjemahkan ke bahasa asing (misalnya bahasa Inggris) harus dilakukan dengan hati-hati, teliti, dan tepat. Penelitian ini tentang penerjemahan dokumen akademis tersebut di UIN Sunan Kalijaga Yogyakarta menemukan bahwa, walaupun secara umum terjemahannya benar, ada banyak bagian dokumen yang belum diterjemahkan secara takurat. Ketidakakuratan tersebut terjadi karena sering terjadi ketidakkonsistenan dalam memilih diksi (atau kosa kata), struktur frase, dan pilihan prosedur terjemahan yang tidak sesuai. Oleh karena itu, keselarasan, keseragaman, dan konvensi terjemahan diperlukan untuk menjaga kualitas hasil.

Kata kunci: terjemaha; proses krusia; konvensi

How to Cite: Witriani. Sari, U. R. Fudiyartanto, F. A. (2017). Lost In Translation and the Crucial Process of Convention. IJEE (Indonesian Journal of English Education), 4(1), 97-110. doi:10.15408/ijee.v4i1.6598. 


\section{INTRODUCTION}

When the State Islamic University (UIN) Sunan Kalijaga is preparing to be a World Class University, the issue of foreign languages, especially Arabic and English, is one of the most important elements to consider. Not only because being 'go international' requires standardization that should be achieved, especially of the services and quality of all the stakeholders, but also because of the importance of informative and reliable standards for all parties in the university.

Related to the standardization, except the name of the university, i.e. Universitas Islam Negeri that has been translated into State Islamic University, there are rarely official translations for institutional names (faculty, department, and other institutions) and other documents such as degree certificates and academic transcripts. Each institution and department has its own translation for those documents without any legality or standard of references. Even, the procedure of translation in the Language Center of UIN Sunan Kalijaga - an institution where the students, faculty or alumni seek for translating their certificates, abstract and transcripts - is only handed over their translators (appointed by the Language Center) and then edited by the language coordinator either in Arabic or in English Language.

This of course may become a problem, especially on the validity of translation of those various documents. In addition, this institution also does not have some legal translators whose work are legally and scientifically reliable and defensible. Not surprisingly, a variety of translated documents at the university level, the faculty and the Language Center will have different form of translations terms and similar documents.

Likewise, the research, workshops and alignment of academic documents translation in English is so important and emergency since the goal of university is to have such an international brand or recognition. Furthermore, this research focuses on problems on translation such as the result of translation of academic documents UIN Sunan Kalijaga Yogyakarta, the translation procedures to be taken in interpreting the terms of academic papers of UIN Sunan Kalijaga Yogyakarta from Indonesian into English, and the kinds of alignment of academic documents to be used as reference in the English translation at all levels of the document.

The result of this research can be used as a reference at all levels in this university and also similar contexts. 
Hence, through an academic document alignment workshop, there is a reference English translation of all documents particularly for academic transcripts and certificates from the department to university level.

\section{Theoretical Framework}

Using a language approach, Catford (1965, cited in Nababan, 2008) views the activities of translation and defines them as "the replacement of textual material in one language (SL) by equivalent textual material in another language (TL)", which is defined as "the process of replacing a text of the source language with subtitles target language (p. 19)". He also defines translation as the replacement materials source language text with the target language text material. Newmark (1988) also provides a similar definition, but even more clearly: "rendering the meaning of a text into another language in the way that the author intended the text", which means "to translate the meaning of a text into another language in accordance with its intended author". Furthermore, Kridalaksana (1985, cited in Nababan, 2008) defined translation as the transfer of a message from the source language into the target language by first revealing its meaning and then style language.

According to Nababan (2008), the process (translation) is a series of activities done on purpose. The translation process can also be interpreted as a series of activities carried out by an interpreter at the time he transferred the mandate of the source language to the target language. Therefore, in conducting these activities, a translator must be careful because an error in one phase will cause errors in the subsequent stages. If that happens, the result of translation will contain errors and misleading. Generally, according to Nababan (2008) the translation process consists of three stages:

\section{Analysis of the source language text}

The analysis of the source language text is realized in reading activities that are meant to understand the content of the text. The understanding of the text content requires an understanding of the linguistic elements and extra-linguistic contained in a text.

\section{The transfer of messages}

Once the meaning and structure of the source language are understood, the message contained in them can be identified. The next step is to shift the content, meaning, the message contained in the source language to the target language. This process is an internal process that takes place in the mind of the interpreter, who is then 
expressed in the target language orally or in writing. To obtain a better translation to suit the purpose of translation itself, the translation needs to be aligned.

\section{Restructuring}

Restructuring or alignment is to change the process of transferring into a stylistic form that matches the target language, reader, or listener. Thus, at this stage of this alignment, a translator needs to consider a variety of language to define a style that matches the type of the translated text. They need to consider to whom the translation is intended.

Of the translation process, it can be concluded that the meaning is the main thing to be concerned and translated. To get the meaning, a translator must fully understand the text to be translated. After getting the intended meaning, then he translates it into another language, through the reconstruction of a language without reducing the intended meaning. This is consistent with what was presented by Larson (1984) that said, basically "translation consists of transferring the meaning of the source language into the receptor language (p. 3)". It can be interpreted that the translation is a transfer of meaning of the source language to the target language. That means the main focus or concern of every translator is the meaning (meaning). Larson (1984) also required every translator should be able to "communicating the same meaning in a second language (the receptor) as was communicated in the first (the source) (p. 36)". The translator is able to convey the meaning of the source language in the same meaning of target language.

Based on the understanding and focus of emphasis in the translation above, Larson (1984) distinguished two types of translation, namely: formbased (form oriented) and meaningbased (emphasizing the meaning) as the two opposite poles. Form-oriented translation would tend to lead to a literal translation / literal, while the meaning based translation will lead to idiomatic translation. In practice, in between the two poles there are still other translations models.

Technically, related to the translation of the smaller units, the task of a translator is to choose and use appropriate procedures in order to obtain equivalence word, phrase or sentence. According to Newmark (1988), the translation procedure in a certain way is translating the sentence or the smallest unit of a language. In addition to Newmark, there are other experts also offering translation procedure that Vinay and Darbelnet (in Hatim \& Munday, 2004. The 
procedures offered by Vinay and Darbelnet are as follows:

Method:

- Direct Translation: (1) Borrowing, (2) Calque, (3)Literal translation

- Oblique translation:

Transposition, (2) Modulation, (3) Equivalence (cultural equivalence), (4) Adaptation (descriptive equivalence)

Although there has been a theory of translation procedure, and translators attempt to retain the meaning of the source language to be delivered as precisely as possible in the target language, in practice, there is often found what by Nida and Taber (1974) refer to as "loss of semantic content" or deletion components of meaning (either a lot or a little) p. 106$111 "$. In this sense, the term of content or message is selected by Nida \& Taber (1974) to refer to the sense of meaning that is preferred by Larson and Newmark, as mentioned above. That is, these three terms refer to the same concept, namely: the meanings (as a couple of forms or form of language).

Generally, according to Nida and Taber (1974), the problem of meaning component deletion is especially common for translation related to: (1) idioms, (2) [non/] figurative meanings, (3) shifts in central components of meaning, (4) generic and specific meanings, (5) pleonastic expressions, (6) special formulas, (7) redistribution of semantic components, [and] provision for contextual conditioning.

\section{METHOD}

This study used a design or descriptive qualitative strategies in order to explain with words, not numbers, translation of cases of academic texts in UIN Sunan Kalijaga (Kothari, 2004; Creswell, 2009). A method of data collection was done through a study of academic written or electronic documents that have been translated into English from the agency / institution in UIN Sunan Kalijaga. Data analysis was performed qualitatively, using content analysis or careful analysis of documents (Krippendorff, 2004). In addition, the contrastive analysis was also used to carefully to compare between the source language texts with a target language (Willems et al., 2003). Technically, after the data collection was completed, the researchers conducted a verification and coding on the data prior to analysis. Furthermore, the results of the analysis were aligned in the form of workshops and focus group discussions with experts and practitioners of translation as well as linguists. 
FINDINGS AND DISCUSSION

\section{Analysis of Academic Document Translation}

The purpose of the study is to realize a reference of English translation in all academic documents, especially transcripts and certificates from the department to university level in UIN Sunan Kalijaga. Thus, research data were obtained from academic documents, written or electronic that has been translated into English by agencies/ institutions at UIN Sunan Kalijaga Yogyakarta. Once collected, the data were then analyzed and verified to obtain maximum results.

From the analysis, it is found that each translation indicates a lack of quality both in written or electronic academic translation. The first result showed some inconsistency of translation. The second showed some ambiguous terms in the document translation. The third result indicated grammatical problems in the document translation. The fourth result showed lexical issues, and the last final result indicated a problem of punctuation in the translated documents.

Concerning the inconsistency of translation, especially in the use of certain language elements in the document translation, there are several categories of the inconsistencies found in the translation of data research. The first problem is the lack of consistency in translating the Islamic terms. The second is lack of consistency in translating of phrase structure. The third is lack of consistency in the choice of words (lexical items). The last is lack of consistency in the translation of technical terms.

The first problem is lack of consistency in translating the Islamic terms. Here, translators mostly use two different translation procedures: naturalization and literal translation (word for word). With different procedures, the results will indeed be different. Naturalization has a tendency in maintaining the form of origin words with a slight adjustment to the target language. Literal translation, on the other hand, does not retain its original form, but turn it into the target language. Thus, naturalization will produce different translations compared to the literal translation. For example madhab, sharia, da'wah, Quran, hadith, tawheed, tafseer, madrasah Ibtidaiyah, Ushuluddin, maqashid, zakat, tajweed, infak, and shodaqoh are translated by naturalization procedures, while Islamic Education, tithe, and theoretical use are translated by literal translation (word for word).

The second problem is lack of consistency in terms of phrase 
structure. Phrases in English should follow the existing rules, adapted to its adjectives and nouns. In the data, some improper phrases, order, affixation and diction or choice of words were found. The examples are State Islamic University Sunan Kalijaga that should be Sunan Kalijaga State Islamic University Yogyakarta, Center for Language Development that should be Language Development Center, and Islamic Jurisprudence and the Principles which is supposed to be Principles of Islamic Jurisprudence.

The third problem is a lack of consistency in the diction or choice of words. In several examples, the translators use different words to translate similar terms. It can interfere the reader's understanding, for examples, undergraduate degree and bachelor degree for sarjana; honor and cum laude honors, very and highly satisfactory, satisfactory and fair for predicate of graduation; the major and study program for majors or courses of study; undergraduate thesis and final assignment for the thesis; Grade Point Average and Cumulative Achievement Index's for Indeks Prestasi Akademik (IPK); and sealed and stamped for legality

The fourth problem is lack of consistency in technical terms. There are some typing errors in official documents of translation. The examples are the use of decree in certificates and academic transcripts (in FISHUM), typing error as well as capital letters (capitalization) in the name of the faculty and academic transcripts.

In addition to inconsistency, the research found some ambiguous terms (taxa) in the translation document. Ambiguity in this document due to the amount of its modifier and noun: 2 modifiers 1 noun or 1 modifier attached to 2 nouns, for examples Civil Law and Islamic Business (Hukum Perdata dan Bisnis Islam), Criminal and Constitutional Law/Constitutional Law and Political Islam/ Islamic Constitutional Law and Political Islam (Hukum Tata Negara dan Politik Islam), Islamic Primary School Science (Sains MI), Library Science and Information (Ilmu Perpustakaan dan Informasi) which were supposed to be Library and Information Science/Studies, Center for The Study and Caligraphy Production (Pusat Study dan Produksi Kaligrafi), Center for the study of Art and Cultural Media (Pusat Study Media dan Seni Budaya), Introduction to Sociology Anthropology, and Early Detection on Development.

Furthermore, the present study also found problems with grammar in document of translation. Grammar issues found are the use of singular and plural forms of a word, use adjective and nouns, and spelling mistakes. Social 
and Humanity Sciences, Comparative religion/s, Sociology of Religion/s, Islamic Education for Islamic Primary School/s, Religion and Conflicts Resolution Studies, Maqashid Study and Analysis Strategy (Kajian Maqasid dan analisis strategi), Center for study/the study of Enterpreneuship, Institute for Foreign Language/s, History of Minority Islam/ Islam Minority, History of Islamic Social in Indonesia, Philosophy of Human Being/s, Cross Cultural and Religion Psychology, Qualitative/Quantitiatve Research Method/s, Laboratory of Philosophy "Hikmah" (Laboratorium Filsafat "Hikmah"), University Services Unit >> University Service Units, Public Srevices Unit/ Public Service Units, Civil Servants Indonesia (Pegawai republik Indonesia), On (date), Historical Philosophic Approach, Mathematic, Introduction Sistem Theories, Function of Complex Variabel/s, Development of Special Children and Teenage, Advocatory, Anthological Hadith.

Further findings were related to problems of lexical or choice of words for the translation of a term. In the translation, there are some inappropriate words to be translated into certain terms. This is related to improper diction. Examples found in the data are the Information for Broadcasting, Counseling on Family and Society, Law/Legal Science, Islamic Education, Centre for Gender Mainstreaming and Children's Rights,
Technical Implementation Unit, Psychology of Learning Islamic Education, Value Letter/ Grade for a letter grade, Point/ Credit for credits, value/ Grade Point for the number value, Cooperative Enterprises, Ethics/ Islamic Mysticism, Projective Psychology, Indonesia/ Indonesian Language, Islamic Legal Principles vs. Principles of Islamic Jurisprudence, an undergraduate degree course.

The final findings are in terms of punctuation errors in the translation document. In the data, improper uses of commas and full stop are found. Translators do not write a comma (,) to mention a few things that are in sequence. Instead, the translators use a full stop (.) for the phrases. Examples found in the data are such as the Center for Neuroscience Health and Spirituality; Center for Language, Culture and Religion (Oxford Comma); Awarded in Yogyakarta on the sixteenth of October year two thousand thirteen; Alms Tax and Endowment.

\section{Translation Procedures Analysis}

From the point of view of the procedure used, the problems of translation of academic documents in UIN Sunan Kalijaga are generally due to incorrect translation procedure use of a unit in certain meanings. The procedure used by the translators does 
not fit the context at hand. These errors can reduce the quality of translation since this may cause the deletion occurred or errors of meaning and structure. The following is the explanation with analysis of each case.

Related to the first procedure, generally the choosing of procedures in words absorption (borrowing) is often performed for special terms (jargon) in their respective areas of study courses and faculty. Thus, as mentioned in the previous sections, most of the selection procedures are appropriate, for example Pancasila, the Quran, or Hadith (which is a translation of the Pancasila, the Quran, and the Hadith). However, there are some terms that are not accurately translated using the method of borrowing, because they result in incomplete data components of meaning or shifts in central components of meaning to the readers of the target language (English), for example, the use of the word Tawheed and Tafseer in academic transcript of Propagation Management. If only such course, English language readers will be likely difficult to understand these two terms without the help of the English term. The readers will be easier to understand if the translation of the terms is added with an English term for both, which can be written in parentheses, becomes: Tawheed (Islamic Theology) and Tafseer (Exegesis).

The procedure of absorbent structure (calque) is generally used for typical phrases that perhaps in the field of study or faculty, and the elements forming the words are common phrases in English. Data show that the majority of the selection procedure are appropriate, for example: Ministry of Religious Affairs, State Islamic University, and Islamic Education. However, there are some cases of improper translations using this procedure. For example, the term Civil Law and Islamic Business are not right to interpret the terms of Civil Law and Islamic Business. Indeed, in terms of elements forming phrases/ terms, diction of civil, law, Islamic, business have been commensurate with the words of civil law, Islamic, businesses separately. However, when the translator chooses the calque procedure and translates into Civil Law and Islamic Business, so here the inaccuracy of the election procedure occurs. In this case, there have been shifts in the central components of meaning of the source language to the target language. In terms of Civil Law and Islamic Business, word of Islam is attached to both the Civil and Business, while the word of law is also attached to both. Supposedly, in the structure of the 
English language, the term is translated to: Islamic Civil and Business Law (understood as Islamic Law on Civil and Business).

The third procedure is a literal translation (literal or word-for-word translation). Basically, this procedure will be appropriately used to translate the structural and lexical terms that are not much different between the Indonesian and English languages. Terms such as Comparative Religion, Islam and Local Culture are some examples of literal translation using appropriate procedures. However, there are some cases of improper translation using this procedure, for example, the term Cumulative Achievement Index is not appropriate to translate the term grade point average. Indeed, in terms of elements forming phrases/terms, each of words of cumulative, achievement, the index has been commensurate with the cumulative word, accomplishments, and indexes separately. However, when the translator chooses the literal procedure and translates it into Cumulative Achievement Index, the inaccuracy of the election procedure occurs. In English, the term of Grade Point Average is more acceptable rather than Academic Performance Index.

The fourth procedure, a shift (transposition), can be done to translate the language of something that naturally does need a shift in the class word, the level of structure, or sequence of words. Most of the translations of academic documents in UIN Sunan Kalijaga that apply this procedure have been appropriate, for example, The undersigned (translation of Yang bertanda tangan di bawah ini), although there is a shift from two-word adjective phrase to six-word noun phrase. However, the data show there are also some inappropriate translations when the transposition procedure is applied, for example, the term Science of Prophetic Tradition (translation of Ilmu Hadis). Here the translator is less proper in applying transposition procedure, with the shift from two-word Indonesian phrase into four-word prepositional phrase of English. It would be better if that term is translated into a more acceptable Hadith Studies in English.

The fifth procedure is a change of perspective (modulation) between Indonesian and English, such as the perspective of active-passive or positive-negative. Not many translation data of academic documents in UIN Sunan Kalijaga apply this modulation procedure, one example is a term born (translation of lahir). But there are also cases of translation using this modulation method become inappropriate, for example, the term it 
is hereby certified that (translation from dengan ini menyatakan bahwa). Supposedly, active perspective in Indonesian perspective is better maintained (active) in English, so this becomes hereby certifies that, because the subject of the sentence/clause already exists (ie, the faculty).

The sixth procedure is the cultural equivalent (equivalence) that is used to translate idioms and fixed expressions that are typical Indonesian. For example, to translate the term Islamic Mysticism Sufism, or Quranic Exegesis to translate Tafsir believed was correct. Although much has been correct, there are also some improper translation results when using this equivalence procedure. For example, the term Islamic Jurisprudence and the Principles were chosen to translate Figh / Usul Figh believed to be incorrect. Replacement of Islam typical terms with more neutral but incorrect would cause shifts in central components of meaning of the Indonesian which bring Islamic culture in the English translation.

The seventh procedure is an adaptation or adjustment (adaptation), both in structure and vocabulary, in the absence of the appropriate equivalent in the target language. Cultural factors probably contribute also influence the selection procedure. Data show that most of the selection procedure and in the translation of academic documents are correct, for example, the phrase correct and true to the original which is a translation of the original suit. Even so, the data also showed their election adaptation improper procedures, such as in the case of the translation of the term of the Faculty of Adab and Humanities became the Faculty of Adab (Letters). The elimination of the element of Cultural Studies in English translation is clearly inappropriate, while adding the letters typical to British culture is still acceptable.

When viewed from the perspective of loss of semantic content that occurred in the seventh election error translation procedure above, shifts in the central component of meaning seems the most common. It is indeed very unfortunate, because the academic documents should not be translated recklessly or inadvertently, let alone to result in components deletion of meaning of the original manuscript in Indonesian language.

\section{Translation Results Alignment}

Observing the phenomenon of the finding of inaccuracies in the translation of academic documents UIN Sunan Kalijaga as has been described above, the researchers have conducted several improvements over the alignment and inaccuracies that have 
been found in the data. First, alignment is mainly focused on some problems that occur repeatedly, such as in the case of translation inconsistency: either in relation to the terms of Islam, the phrase structure, choice of words (lexical items), as well as technical matters such as punctuation. Translation should be consistent, there should be no difference in terms and others, either in the text or in academic texts. Here are some examples of the alignment of the data found.

In addition, the data also show that some of the translations are incorrect or inaccurate due to changes in the meaning or significance. Relating to the cases, alignment needs to be done to correct them. Translation inaccuracies category may include errors or inaccuracies of electoral structure vocabulary in context. Here is an example of harmonization on such matters.

In further detail, all documents for each academic study programs in all faculties in UIN Sunan Kalijaga Yogyakarta sampled in this study have been conducted and analyzed alignment in the workshop. However, because they are quite a lot and detailed, the document is not shown here.

Table 1. Sample Alignment with Consistency

\begin{tabular}{|c|c|c|}
\hline No. & Translation Variation & Alignment \\
\hline 1 & $\begin{array}{l}\text { Center for Language Development } \\
\text { Language Development Center }\end{array}$ & Center for Language Development \\
\hline 2 & $\begin{array}{l}\text { Study of Culture } \\
\text { Cultural Studies }\end{array}$ & Cultural Studies \\
\hline 3 & $\begin{array}{l}\text { Islamic Jurisprudence and the Principles } \\
\text { Principles of Islamic Jurisprudence }\end{array}$ & Principles of Islamic Jurisprudence \\
\hline 4 & $\begin{array}{l}\text { Undergraduate degree } \\
\text { Bachelor degree }\end{array}$ & Bachelor degree \\
\hline 5 & $\begin{array}{l}\text { Honor/cum laude } \\
\text { Very/higly satisfactory } \\
\text { Satisfactory/fair }\end{array}$ & $\begin{array}{l}\text { Cum laude } \\
\text { Highly Satisfactory } \\
\text { Satisfactory }\end{array}$ \\
\hline 6 & $\begin{array}{l}\text { Hadith } \\
\text { Prophetic Tradition }\end{array}$ & Hadith \\
\hline 7 & $\begin{array}{l}\text { Zakat } \\
\text { Tithe }\end{array}$ & Zakat (Obligatory Alms) \\
\hline
\end{tabular}


Table 2. Example of Coordination with Correction

\begin{tabular}{|c|c|c|}
\hline No. & Wrong Translation & Alignment \\
\hline 1 & $\begin{array}{l}\text { Civil Law and Islamic Business } \\
\text { (Hukum Perdata dan Bisnis Islam) }\end{array}$ & $\begin{array}{l}\text { Islamic Civil and Business Law } \\
\text { (Islamic Law on Civil and Business) }\end{array}$ \\
\hline 2 & $\begin{array}{l}\text { Islamic Constitutional Law and Political Islam } \\
\text { (Hukum Tata Negara dan Politik Islam) }\end{array}$ & Islamic Constitutional and Political Law \\
\hline 3 & $\begin{array}{l}\text { Library Science and Information } \\
\text { (Ilmu Perpustakaan dan Informasi) }\end{array}$ & Library and Information Science \\
\hline 4 & $\begin{array}{l}\text { Social and Humanity Sciences } \\
\text { (Ilmu Sosial dan Humaniora) }\end{array}$ & Social Sciences and Humanities \\
\hline 5 & $\begin{array}{l}\text { History of Islamic Social in Indonesia } \\
\text { (Sejarah Masyarakat Islam Indonesia) }\end{array}$ & History of Indonesian Islamic Societies \\
\hline 6 & $\begin{array}{l}\text { Psychology of Learning Islamic Education } \\
\text { (Psikologi Pendidikan Islam) }\end{array}$ & Psychology of Islamic Education \\
\hline
\end{tabular}

\section{CONCLUSION AND SUGGESTION}

The analysis of the data shows some important and fundamental that the conclusion in this study. First, most of the academic documents studied had been translated appropriately. However, some parts of the document are still relatively widely found errors/translation inaccuracies, both in terms of structure and vocabulary, which can affect the meaning (generally occur the deletion of meaning). Secondly, all the translation procedures have been used by the translator: some of the procedures are appropriate to use, but others are still improper use. Third, the alignment of the translation of academic documents is necessary to maintain consistency: meaning, structure, or vocabulary.
Associated with some of the above problems, there are formulated some suggestions that are worth to consider. The first is the establishment of a discussion forum as a media translator. The second is the use of a standard for document translation and the name of the institution. The third is to test the translator (Language Proficiency and Translation Accuracy). The latter is a verification (crosschecking) of data with a trusted source.

\section{REFERENCES}

Creswell, J. W. (2009). Research design: Qualitative, Quantitative, and Mixed Methods Approaches (3rd ed.). California: Sage Publication. 
Hatim, B., \& Munday, J. (2004). Nababan, M. R. (2008). Teori menerjemah Translation: An advanced resource Bahasa Inggris. Yogyakarta: book. New York: Routledge. Pustaka Pelajar.

Kothari, C. R. (2004). Research Newmark, P. (1988). A textbook of methodology: Methods and techniques (2nd ed.). New Delhi: New Age International.

Krippendorff, K. (2004). Content Analysis: An introduction to its methodology (2nd ed.). California: Sage Publication.

Larson, M. L. (1984). Meaning-based translation: Guide to cross-language equivalence. Lanham: University Press of America. translation (1 $1^{\text {st }}$ ed.). London: Prentice Hall.

Nida, E. E., \& Taber, C. R. (1974). The theory and practice of translation. Leiden: E. J. Brill.

Willems, D. et al. (Eds.). (2003). Contrastive analysis in language: Identifying linguistic units of comparison. New York: Palgrave Macmillan 